\title{
Real interest rate convergence and monetary policy independence in CEE countries*
}

\author{
Milan Deskar-Škrbić1 , Antonija Buljan², Mirna Dumičićc ${ }^{3}$
}

\begin{abstract}
In this paper we provide new empirical evidence relevant for discussions on monetary policy independence in the context of euro adoption in three Central and Eastern European (CEE) countries: Czechia, Hungary and Poland. Unlike many other authors, in this paper we focus on real and not nominal interest rates as real interest rates are at the hearth of modern macroeconomic and monetary policy theory. In the paper we employ several methodologies to test the convergence of real interest rates between these countries and the euro area and to determine the main drivers of real interest rates. Based on the unit root analysis we find evidence of convergence of real interest rates in these countries, thus confirming the real interest rate parity (RIRP) hypothesis. Next, using principle component analysis (PCA) we show that common factor extracted from the sample of CEE countries and individual euro area countries can explain high proportion of real interest rate developments in these countries. Finally, results of our newly proposed analytical framework for the analysis of determinants of real interest rates in small open economies, based on a Bayesian VAR model with block exogeneity, show that external shocks have non-negligible effect on real interest rate developments in selected CEE countries. Thus, our results indicate that real interest rates in CEE depend on factors that are beyond the scope of domestic monetary policy makers. In this sense we can conclude that (conventional) monetary policy independence in these countries is limited. Thus, we see the loss of monetary policy independence as overly emphasized argument in discussions on the euro adoption in these countries. However, we are aware that national central banks in CEE started to
\end{abstract}

* Received: 02-03-2020; accepted: 11-11-2020

1 Senior Economic Researcher-Advisor, Croatian National Bank, Modelling Department. Scientific affiliation: applied macroeconometrics, economic policy, macroeconomics of small open economies.Phone:+38514590313.E-mail:mdeskar@hnb.hr.

2 Teaching and research assistant, University of Zagreb, Faculty of Economics and Business, Department of finance. Scientific affiliation: public finance, fiscal policy, taxation. Phone: +385 1238 3170.E-mail: abuljan2@net.efzg.hr.

3 Chief Advisor, Croatian National Bank, Financial Stability Department, Scientific affiliation: macroprudential policy, financial stability, macroeconomics of small open economies. Phone: +38514564879.E-mail:mirna.dumicic-jemric@hnb.hr. 
rely more on non-conventional measures recently, which gives them a higher degree of flexibility (and autonomy).

Key words: euro adoption, real interest rate parity (RIRP), real interest rates, BVAR - Bayesian VAR model, CEE, optimal currency area (OCA)

JEL classification: E32, E52, F45

\section{Introduction}

Theoretical and empirical literature in the field of international macroeconomics indicates that the loss of monetary policy independence ${ }^{4}$ represents the most pronounced cost of joining the common currency area (e.g. Eudey, 1998; Alesina et al., 2002; Angelloni et al., 2007; Edwards, 2015).

Discussions on the monetary policy independence are especially interesting in Europe as the Economic and Monetary Union (EMU) is founded with the goal and ambition that all member states of the European Union (EU) will gradually adopt the common currency and complete the decades-old idea of full economic integration in the EU. Out of twenty-seven EU member states, nineteen adopted the euro since its introduction in 1999. Most of remaining eight non-euro area member states are legally bound to adopt the euro eventually by the provisions of the EU Accession Treaties. The group of the non-euro area EU members includes two old member states, Denmark and Sweden, and six new member states, Bulgaria, Croatia, Czechia, Hungary, Poland and Romania. All countries are formally obliged to introduce the euro, except Denmark, as this country negotiated a so-called opt out option in 1992.

New member states that have not adopted the euro yet are all located in the Central and Eastern European (CEE) region. Three of them, Bulgaria, Croatia and Romania are on the path towards the monetary union and euro adoption (Deskar-Škrbić et al., 2020), while other three countries, Czechia, Hungary and Poland, decided to postpone the discussion on euro adoption indefinitely (Deskar-Škrbić and Kunovac, 2020). The latter three countries, which are in the focus of our analysis, operate in the inflation targeting monetary policy regime, with flexible exchange rates, and use the policy rate as the key monetary policy instrument. Thus, policy makers in these three countries see euro adoption as a threat to the monetary policy independence.

However, theoretical and empirical literature show that monetary policy independence in small open economies ${ }^{5}$ can be fairly constrained, especially in

\footnotetext{
4 Aizenman et al. (2013) define the monetary policy independence as the ability of the national central bank to set interest rates independently from international interest rates.

5 A small open economy is an economy that participates in international trade, but is small enough compared to its trading partners that its policies do not alter world prices, interest rates, or incomes. All countries in the CEE region can be described as small open economies.
} 
small open economies that are strongly integrated with major markets. ${ }^{6}$ On the one hand, there are several exogenous factors that motivate small open economies to adjust their monetary policy rules towards an open economy version of Taylor rule and implicitly or explicitly include major market interest rates in their monetary policy reaction function (Edwards, 2015). ${ }^{7}$ First is the so-called fear of float argument (Calvo and Reinhart, 2002). In this case, monetary policy measures are directed on limiting exchange rate volatility by avoiding wide interest rate differentials that could lead to large capital flows. Second, monetary policy makers in small open economies should carefully monitor monetary policy moves in major markets because there are strong spillovers of major markets monetary policy directly to macroeconomic variables in small open economies, mostly through the trade channel (Rodseth, 2004; Ca'Zorzi et al., 2020). Third, due to high level of trade integration among countries, especially in economic unions such as the EU, inflation rates tend to move in a similar manner. Thus, inflationary or deflationary monetary policies by major markets will eventually spill over to small open economies, triggering their monetary policy reaction (Macchiaelli, 2013). These factors can be seen as exogenous restraints to monetary policy independence in small open economies. On the other hand, correlation of interest rates in small open economies and major markets can also be endogenously driven by the synchronization of business cycles and coherence of economic shocks (Goczek and Mycielska, 2019; Deskar-Škrbić et al., 2020). ${ }^{8}$ More precisely, if economic developments in small open economies and major markets are driven by some common shocks, reactions of monetary policies in these countries will be fairly similar, without small open economies taking into account monetary policy decisions in major markers.

All these factors suggest that there should be not only high level of correlation and/or convergence in nominal interest rates between small open economies and major markets but also real interest rates. And real interest rates are at the hearth of modern macroeconomics and monetary policy analysis (Woodford, 2003; Gali,

\footnotetext{
${ }^{6}$ Capital mobility is one of the corner stones of the EU which led to strong integration of financial markets and triggered capital flows from the euro area to the CEE region. Euro area-based bank groups dominate local banking sectors in the CEE, most of FDI inflows in the CEE region originates in the euro area, euro area-based institutional investors hold the largest share of the CEE sovereign debt etc. Thus, even countries with flexible exchange rates in CEE region can find it hard to pursue independent monetary policy so the Mundellian trilemma boils down to the "dilemma" (Rey, 2015).

7 Unlike closed economy Taylor rule that is based on domestic inflation and output gap, open economy version includes exchange rate and/or foreign interest rates.

${ }^{8}$ Beside these mechanisms that primarily work through conventional monetary policy tools, there are other channels of international transmission of monetary policy, which are mostly related to the effects of unconventional monetary policy. Papers investing these channels for the CEE are, for example, Prettner and Prettner (2014) and Feldkircher (2015). Generally, empirical literature shows that unconventional monetary policy spillovers from the euro area to CEE countries are fairly pronounced (for literature review see Benecka et al., 2018).
} 
2008; Walsh, 2010; Carlin and Soskice, 2014). In modern macroeconomic models decisions of households and investors depend on real interest rates, while the role of monetary policy authority is to steer the real interest rate towards the natural level in order to close the output gap and stabilize inflationary or deflationary pressures. ${ }^{9}$ To put it in the context of macro and monetary theory, real interest rates determine the relationship between IS-curve, Phillips curve and monetary policy rule in dominant New Keynesian macroeconomic models. Thus, when we discuss monetary policy independence in CEE region, unlike many other authors, in this paper we do not focus on nominal interest rates but real interest rates. ${ }^{10}$

More precisely, in this paper we analyze de facto ${ }^{11}$ monetary policy independence in three CEE countries, Czechia, Hungary and Poland, by analyzing the convergence of real interest rates in the context of real interest rate parity (RIRP) and investigating the main drivers of real interest rates in these countries and the euro area. The focus of our analysis is on these countries as all of them pursue inflation targeting strategy with (mostly) flexible exchange rates and they are all reluctant to join the euro area in the near future with the loss of monetary policy independence as the key economic argument against euro adoption (Deskar-Škrbić and Kunovac, 2020).

Our empirical approach is based on several methods. First, in order to test the validity or RIRP we use standard unit root tests and unit root test with endogenous structural break. Second, to analyze whether real interest rates in the euro area and CEE are driven by some common shocks we use principle component analysis (PCA) and simple OLS models. Finally, to determine the nature of shocks that drive real interest rates in selected CEE countries and the euro area we rely on a small open economy Bayesian VAR (BVAR) model with block exogeneity assumption. Structural shocks in this model are identified using sing and zero restrictions, based on economic theory. In the interpretation of our results we focus on historical decomposition that allows us to trace the effects of various shocks to real interest rates over time and to determine the relevance of external shocks to development of real interest rates in selected small open economies.

Our contributions to the literature is twofold. First, to our knowledge, there is no similar analysis that explicitly investigates the contribution of common factors

\footnotetext{
9 As Carlin and Soskice (2014) point out, in modern macro models central bank must adjust the nominal interest rate in order to achieve a particular real interest rate according to the so-called Taylor principle.

${ }^{10}$ In addition, as Cuaresma and Wojcik (2006) explain, strong disinflation process in CEE countries introduced a considerable trend in nominal interest rates that inhibits making proper econometric inferences from estimations using nominal interest rates.

${ }^{11}$ De jure monetary policy independence reflects formal, legal institutional framework, while de facto monetary policy independence reflects the actual degree of monetary policy independence in practice.
} 
to developments of real interest rates in selected countries over time. Second, we offer a novel approach suitable for the analysis of real interest rate developments in small open economies, based on BVAR with block exogeneity assumption. Our hypothesis is that there is a real interest rate convergence between selected CEE countries and the euro area and that the convergence is a result of the fact that real interest rates are determined not only by domestic but also by external (common) shocks.

Next section provides a brief review of the literature on real interest rate convergence and monetary policy independence in CEE region. Section 3 describes the methodology used in the empirical part of the paper, while in Section 4 we present the data and provide relevant descriptive statistics that motivate our analysis. In Section 5 we discuss the results and then draw the main conclusions in the last section.

\section{Literature review}

Our paper builds on three major strands of literature. The first strand of literature deals with the so-called real interest rate parity and convergence of real interest rates among countries, with the focus on relations between small open economies and major economies. The second strand is focused on international spillovers of economic shocks between major economies and small open economies. Finally, third strand of literature is focused on monetary policy independence in small open economies. However, the literature is fairly extensive in this review we mostly focus on papers that are concentrated on the euro area and CEE region.

\subsection{Real interest rate parity (RIRP)}

There are three fundamental relations in international macroeconomics: uncovered interest parity (UIP), purchasing power parity (PPP) and Fisher's equation (Obstfeld and Rogoff, 1996). If the first two parities hold, combined with the Fisher's equation, they lead to a notion that real interest rates should be equal across countries. ${ }^{12}$ Equalization of real interest rates across countries became popular as the "real interest rate parity" (RIRP). ${ }^{13}$

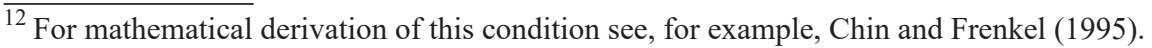

${ }^{13}$ The RIRP was popularized in empirical works by prominent economists during the last two decades of the twentieth century (e.g. Mishkin, 1984; Mark, 1985; Cumby and Mishkin, 1986; Meese and Rogoff, 1988; Dutton, 1993; Goodwin and Grennes, 1994; Wu and Fountas, 2000; Obstfeld and Taylor, 2002).
} 
This parity represents an important measure of international financial markets integration and has notable repercussions for monetary policy. As Mark (1985) states, if the RIRP holds, the ability of domestic monetary authority to affect domestic real interest rates and other variables that depend upon them will be severely limited to the extent to which the monetary authority can affect the global real interest rate. ${ }^{14}$ Although the validity of the RIRP is important on the global level, special interest for this topic was triggered by the euro introduction in 1999. The third stage of the EMU brought together countries with different structural characteristics and united them under the "umbrella" of the common central bank, the ECB (e.g. Holmes, 2002; Holmes, 2005; Ferreira and Leon-Ledesma, 2007). Effectiveness of the monetary transmission mechanism in European monetary union heavily depends on the validity of the RIRP (Aksoy et al., 2002). Arghyrou and Gregoriou (2007) point out that for transmission to be uniform, national real interest rates against the EMU average must be mean-reverting and display similar persistence patterns. If the opposite is true, shifts in the eurozone average-oriented ECB policy would result in intra-EMU asymmetric monetary shocks. The RIRP is also an important indicator of the level of integration of the non-euro area countries with the euro area and can be used as one of the optimum currency area (OCA) indicators. If non-euro area member states fulfill nominal convergence criteria, which suppose convergence of interest rates, inflation rates and stability of exchange rates, the RIRP should hold. Thus, in discussions on the future of the euro area enlargement it is important to analyze the RIRP validity in the non-euro area CEE countries.

The literature dealing with the validity of RIRP in CEE is relatively abundant. In order for the RIRP to hold in the CEE, real-interest rate differentials should be stationary, i.e. there should be a convergence of real interest rates between the CEE countries and the euro. That is why most papers in this strand of literature are based on different unit root tests. For example, Aghrizm et al. (2009) use various unit root tests with and without structural breaks and find evidence of real interest rate convergence between EU new member states (mostly from CEE region) and the euro area. Cuestas and Harrison (2010) use Ng and Perron (2001) unit root test and find evidence in favor of the empirical fulfilment of the RIRP. Su et al. (2012) employ Enders and Lee (2012) unit root test and indicate that the RIRP holds true for CEE countries. Su, Jiang and Chiang (2014) confirmed the RIRP for CEE countries, using the Narayan and Popp's (2010) unit-root test with structural breaks. Overall, papers in this strand of literature point to convergence of real interest rates between CEE countries and the euro area, especially after the Great Recession.

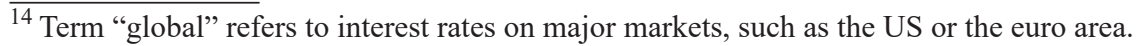




\subsection{International transmission of economic shocks}

As previously explained, convergence in real interest rates will occur more easily if real interest rates in these two regions are driven by some common factors and if their business cycles are synchronized. In this context there is a lot of empirical evidence showing that there is a high level of correlation of business (and price) cycles between CEE and the euro area (e.g. Arčabić, 2011; Stanišić, 2013; JiménezRodríguez et al., 2013; Macchiaelli, 2013; Kotarac et al., 2017; Campos et al., 2019; Botrić et al., 2020). These findings have great importance in the context of the euro area enlargement as they indicate that CEE countries could satisfy important conditions of the optimal currency area (OCA).

However, business cycle synchronization only reflects some deeper relations between CEE countries and the euro area. To put it differently, business cycle synchronization is the result of some fundamental relations. According to Mongelli's (2002) endogenous theory on OCA these deep relations should be sought in the coherence of economic shocks between countries. More precisely, Mongelli (2002) claims that coherence of economic shocks is a "meta property" of OCA because if the same shocks drive economic developments in countries inside and outside the common currency area it means that there is a high level of financial and trade integration between these countries and that there are strong flows of good, capital and even labor. That is why later stages of OCA literature mostly focus on coherence of economic shocks, starting with Bayoumi and Eichengreen (1992) ${ }^{15}$

Literature on the role of euro area shocks in CEE and coherence of shocks between CEE and the euro area mostly ${ }^{16}$ points to notable effects of euro area shocks and a high level of coherence. For example, Mackowiak (2006) uses structural small open economy vector autoregressive (VAR) model with block exogeneity and shows that euro area shocks have economically significant oh Hungary, Poland and Czechia. Horvath and Rusnak (2009) and Hanclova (2012) use similar methodology and find similar evidence in case of Slovakia and Czechia. Iossifov and Podpiera (2014) use panel model and show that there is a strong transmission of euro area prices to domestic prices in CEE region. Felkircher (2015) relies on Global VAR (GVAR) model and shows that euro area shocks have notable effect on macroeconomic developments in CEE countries. Kotarac et al. (2017) follow Bayoumi and Eichengreen (1992) methodology and show that there is a high level of correlation

\footnotetext{
${ }^{15}$ For extensive literature review on OCA see Broz (2005).

${ }^{16}$ Papers with older date are more skeptical in this context. For example, meta-analysis presented in Fidrmuc and Korhonen (2006) indicates that the correlation of economic shocks in CEE and the euro area is low and that euro adoption would be costly. Broz (2010) uses Bayoumi and Eichengreen (1992) approach and concludes that the level of coherence of economic shocks in most CEE countries with the euro area was not on satisfactory level in the context of OCA conditions up to 2006.
} 
of economic shocks between CEE countries and the euro area. Additionally, authors estimate structural BVAR model with block exogeneity and show that economic developments in CEE countries are mostly determined by symmetric and not asymmetric shocks. Finally, Deskar-Škrbić et al. (2020) use Bayesan structural VAR model with block exogeneity to identify various domestic and common shocks (that are relevant for both CEE countries and the euro area) and show that common shocks are dominant determinant of GDP and inflation developments in most CEE countries.

\subsection{Monetary policy independence in CEE}

Finally, our paper is related to the literature that analyzes the degree of de facto monetary policy independence in small open economies from CEE region. This strand of literature indicates that monetary policy independence in most inflationtargeting CEE floaters is constrained by various factors.

Cuaresma and Wojcik (2006) employ dynamic conditional correlation multivariate GARCH (DCC-MGARCH) model and show that none of the three CEE countries enjoy full monetary independence. Benkovskis et al. (2011) analyze the transmission of monetary policy shocks from the euro area to Poland, Hungary and Czechia. They employ a factor augmented VAR (FAVAR) model and show that there are substantial effects of euro area monetary policy on interest rates and economic activity in CEE countries. Kadow et al. (2013) coin a so-called "euro dominance hypothesis" (EDH) and find empirical evidence to prove it in case of CEE countries, using GVAR model. EDH hypothesis states that euro area interest rates dominate money market interest rates in CEE countries, which constrains the monetary policy independence of local central banks. Gosczek and Mycielska (2016) use vector error correction (VEC) model and also find the empirical proof for EDH in case of Czechia. Keppel and Prettner (2015) use structural VECM with sign restrictions and show that increases in euro area interest rates translate into rising CEE interest rates. Dabrowski et al. (2019) use autoregressive distributed lag (ARDL) model and show that there is convergence in nominal interest rates between euro area and CEE countries.

This brief literature review indicates that CEE countries are strongly integrated in euro area trade and financial flows and that there are notable spillovers from the euro area to CEE small open economies. In addition, there is a robust empirical evidence that economic developments in CEE and the euro area are driven by common shocks. This is reflected in a high level of business cycle synchronization, convergence in prices and convergence and synchronization of nominal interest rates on money markets. Thus, we can expect that similar patterns should be reflected also in developments of real interest rates. We turn to this important question in the empirical part of the paper. 


\section{Methodology}

We start our analysis by testing the validity of RIRP hypothesis in Czechia, Hungary and Poland. As previously explained, for the RIRP to hold real interest rate differentials should be stationary. ${ }^{17}$ Thus, we test the stationarity of real interest rate differentials in Czechia, Hungary and Poland vis-a-vis euro area interest rates through standard unit root tests such as Augmented Dickey and Fuller (1979) (ADF), Phillips and Perron (1988) (PP) and Kwiatowski et al. (1992) (KPSS) test. However, these tests do not allow for the possibility of a structural break and thus can provide misleading results. In our sample, structural breaks can occur due to the effects of various factors, such as global financial crisis, European sovereign debt crisis, launch of quantitative easing program by the ECB etc. Thus we additionally employ Zivot and Andrews (2012) test with endogenous structural break.

As RIRP suggests that there is a convergence in real interest rates among countries, in the second step of the analysis we want to determine whether real interest rates in selected CEE countries and the euro area converge because they are driven by some common factors. To assess the contribution of common factors to developments of real money market interest rates in CEE and the euro area, we follow approach proposed in Kunovac (2013). We employ the principal component analysis to extract common factors from the sample of all countries and then regress real interest rate in respective country to principal component(s) and a constant. By multiplying the estimated coefficients with principal component(s) we get the contribution of common factors, while residual represents the contribution of domestic (idiosyncratic) factors.

We can define the factor model as:

$$
R I R_{i t}=\lambda_{i} F_{j}+\epsilon_{i t}
$$

where $R I R_{i t}$ is an N-dimensional vector of multiple time series in countries $\mathrm{i}$ and time periods $t . R I R_{i t}$ includes (standardized) real interest rates in the three CEE countries and individual euro area countries. ${ }^{18} R I R_{t}$ can be expressed as a linear combination of common factors $F_{t}$, while $N x 1$ is an vector of idiosyncratic disturbances. Factors are estimated by method of principle components (PCA).

In the second step, we regress real interest rates of each country on principle components:

\footnotetext{
${ }^{17}$ Bernard and Durlauf (1996) and Estrin and Uraga (1997) indicate that convergence occurs if the long-run differences between time series tend to move to some steady state level.

${ }^{18}$ Besides Czechia, Hungary and Poland in this part of the analysis we additionally include individual euro area countries because PCA on the small sample could produce misleading results. We did not include new member states as the focus of our paper is on the relationship between CEE countries and the euro area.
} 


$$
R I R_{t}=\beta_{0}+\sum_{j=1}^{k} \beta_{j} F_{j t}+e_{t}
$$

We decompose RIR developments on the part explained by common factors $\sum_{j=1}^{k} \beta_{j} F_{j t}$ and the residual $\epsilon_{t}$, which can be interpreted as the domestic (idiosyncratic) factor.

Although this approach gives some interesting insights into the relevance of common shocks for real interest rate developments in selected CEE countries, it is purely empirical. Thus, in the third part of our analysis we give some more theoretical rigor to our analysis by estimating small open economy BVAR model with block exogeneity identified by sign restrictions, based on economic theory.

Structural form of the VAR model for each CEE country of interest can be defined as: ${ }^{19}$

$$
\sum_{s=0}^{p} A_{j} y_{s}=\varepsilon_{t}
$$

Vector $y$ contains all variables in the model that can be divided in two blocks: $y=\left[y_{1}, y_{2}\right]^{\prime}$. External block $y_{1}$ includes external (euro area) GDP $\left(G D P_{t}^{E A}\right)$ and inflation $\left(\pi_{t}^{E A}\right)$, while domestic block $y_{2}$ includes real money market interest rates $\left(r^{t}\right)$, share of investments in GDP $\left(i_{t}\right)$, domestic GDP $\left(G D P_{t}^{D}\right)$ and domestic inflation $\left(\pi_{t}^{D}\right)$.

$$
\begin{aligned}
& y_{1}=\left[G D P_{t}^{E A}, \pi_{t}^{E A}\right]^{\prime} \\
& y_{2}=\left[r_{t}, i_{t}, G D P_{t}^{D}, \pi_{t}^{D}\right]^{\prime}
\end{aligned}
$$

As we explain below, selection of variables is based on economic theory that should help us to identify structural shocks in the model. We are aware that this is not a full set of relevant variables but due to relatively short sample we wanted to keep our model parsimonious. Matrices $A_{j}$ are matrices of structural parameters that determine the relationship between all variables in the model up to period $p$. Vector $\varepsilon_{t}$ is a vector of structural shocks with distribution $M V N(0, \mathrm{I})$. As we have two blocks of variables in our model each matrix $A_{j}$ can be expressed as:

$$
A_{j}=\left[\begin{array}{ll}
A_{11}^{j} & A_{12}^{j} \\
A_{21}^{j} & A_{22}^{j}
\end{array}\right], j=0, \ldots, p
$$

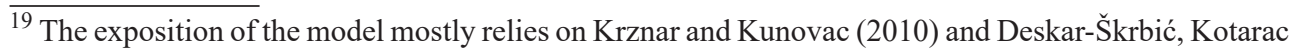
and Kunovac (2020). Model also includes constant. 
As we assume that small open economies in our sample cannot affect economic developments in the euro area we impose block exogeneity assumption $A_{12}^{j}=0$. However, structural VAR model cannot be estimated directly without imposing additional restrictions on $A_{j}$, i.e. without identifying the model (Killian and Lütkepohl, 2017).

However, we can derive reduced form of VAR model by multiplying (3) with matrix $\mathrm{A}_{0}^{-1}$ (this matrix contains contemporaneous relations between variables):

$$
y=\sum_{s=1}^{p} B_{j} y_{t-s}+\eta_{t}
$$

where $A_{0}^{-1} \varepsilon_{t}=\eta_{t}\left(\mathrm{MVN}\left(0, \Sigma_{\eta}\right)\right.$ and $B_{j}=A_{0}^{-1} A_{j}$, for $j=0, \ldots, p$. Matrices $B_{j}$ inherit the block exogeneity assumption:

$$
A_{j}=\left[\begin{array}{cc}
B_{11}^{j} & 0 \\
B_{21}^{j} & B_{22}^{j}
\end{array}\right], j=1, \ldots, p
$$

Although (5) implies (6), the opposite does not hold. Thus, to get (5) from (6) we need to impose additional restrictions on $A_{0}$ (parameters that define impulse response functions on impact) and on VAR parameters. First we impose restriction on $A_{0}$ that small open economies cannot affect euro area at impact $j=0$. Next, the second part of block exogeneity implementation is to shut down the impact of small open economy shocks on external variables beyond the impact $(j=1, \ldots, p)$. We do this within the Bayesian framework that is explained in details in Deskar-Škrbić et al. $(2020) .^{20}$

Structural shocks in (3) are identified using sing and zero restrictions. ${ }^{21}$ We base our identification strategy in the domestic block on Alexius (2017). However, we extend this model with the external block that is identified similar to Deskar-Škrbić et al. (2020). Our identification strategy is presented in Table 1.

\footnotetext{
${ }^{20}$ To implement (6) authors assume zero mean priors with extremely small variance for all the small open economy parameters in every equation of the euro area block. A sample from the posterior of the reduced form parameters and residual covariance matrix is drawn using a Gibbs sampler, with the total number of 3000 iterations and 500 burns. Authors use loose priors in spirit of Minessota priors: $\lambda_{1}=100, \lambda_{2}=100, \lambda_{3}=2, \lambda_{4}=10^{4}$. Estimation is based on toolbox developed by Kunovac and Kotarac (2017).

${ }^{21}$ At each step of Gibbs sampler, given a draw of reduced form parameters, we recover a set of structural models satisfying the imposed sign and zero restrictions. The sign and zero restrictions are imposed directly onto the impulse response function, using the procedure proposed by Arias et al. (2014).
} 
Table 1: Identification strategy

\begin{tabular}{|l|c|c|c|c|c|c|}
\hline Variable & $\begin{array}{c}\text { Domestic } \\
\text { savings } \\
\text { rate } \\
\text { shock }\end{array}$ & $\begin{array}{c}\text { Domestic } \\
\text { productivity } \\
\text { shock }\end{array}$ & $\begin{array}{c}\text { Domestic } \\
\text { cost push } \\
\text { shock }\end{array}$ & $\begin{array}{c}\text { Domestic } \\
\text { business } \\
\text { cycle } \\
\text { shock }\end{array}$ & $\begin{array}{c}\text { External } \\
\text { business } \\
\text { cycle } \\
\text { shock }\end{array}$ & $\begin{array}{c}\text { External } \\
\text { productivity } \\
\text { shock }\end{array}$ \\
\hline Real interest rate & $<0$ & $>0$ & $>0$ & $>0$ & $?$ & $?$ \\
\hline Investments & $>0$ & $>0$ & $<0$ & $>0$ & $?$ & $?$ \\
\hline Domestic GDP & $>0$ & $>0$ & $<0$ & $>0$ & $?$ & $?$ \\
\hline Domestic inflation & $>0$ & $<0$ & $>0$ & $>0$ & $?$ & $?$ \\
\hline Euro area GDP & 0 & 0 & 0 & 0 & $>0$ & $>0$ \\
\hline Euro area inflation & 0 & 0 & 0 & 0 & $>0$ & $<0$ \\
\hline
\end{tabular}

Note: " $>0$ " indicates that shock leads to increase of corresponding variable at impact; " $<0$ " indicates that shock leads to fall of corresponding variable at impact; " 0 " indicates that shock does not affect corresponding variable at impact; "?" indicates that there we did not impose restrictions at impact

Source: Authors

Firstly, we identify four domestic shocks that are relevant for developments of real interest rates. Domestic savings shock leads to decrease in real interest rate, according to standard macroeconomic models. Falling real interest rate stimulates investments, investment growth leads to stronger aggregate demand which leads to rise in inflation rate. Domestic productivity shock leads to increase in GDP and investments (accelerator effect) and fall in inflation. ${ }^{22}$ Falling prices lead to increase in real interest rate. Domestic cost push shock ${ }^{23}$ increases marginal costs of firms, thus leading to fall in investments and GDP, while at the same time it leads to increase in prices (as producers try to shift part of the cost increase to consumers). Monetary policy reacts to cost push factors by increasing nominal interest rate above the increase in inflation (aforementioned Taylor principle), thus increasing the real interest rate. Domestic business cycle shock ${ }^{24}$ leads to accelerating economic activity and investments (accelerator effect), which put pressures on prices. Monetary policy again reacts counter-cyclically by increasing real interest rate. Zeros in in last two rows indicate that domestic shocks cannot affect euro area economic developments at impact. ${ }^{25}$

$\overline{22}$ We can also label this shock as an aggregate supply shock in line with the classification proposed by Bayoumi and Eichengreen (1992).

${ }^{23}$ According to Gali and Gertler (2007) cost push factors come from the labor market in fashion of a staggered nominal wage setting.

${ }^{24}$ We can also label this shock as an aggregate demand shock in line with the classification proposed by Bayoumi and Eichengreen (1992).

${ }^{25}$ Block exogeneity assumption additionaly ensures that domestic shocks cannot affect euro area in all other periods as well. 
We additionally define two external shocks. As in the case of domestic shocks, external business cycle shock leads to increase in the euro area GDP and prices, while external productivity shock leads to increase in euro area GDP and fall of prices. Question marks in the last two columns indicate that we impose no restrictions on the effects of external shocks on domestic variables as we want to get information on the role of external shocks for domestic economic developments from data. In this way our main results, i.e. relevance of external shocks for domestic real interest rate developments, seem more reliable. Finally, we want to emphasize that the label external shock implies that these shocks can originate in the euro area (e.g. European debt crisis) but also outside the euro area (e.g. Global financial crisis, GFC). More precisely, these shocks capture the effects of both euro area and global shocks.

\section{Empirical data and analysis}

The first part (unit root tests) and the second part (PCA and decomposition of real interest rates in OLS regressions) of our analysis are based on monthly data on 3-month money market interest rates obtained from the Eurostat website. Nominal interest rates are deflated by inflation rates calculated from the monthly HICP data, also obtained from the Eurostat website. The period of the analysis ranges from $2004 \mathrm{~m} 1$ to $2019 \mathrm{~m} 12$. Although data is available before 2004, we exclude this period from the analysis as Czechia, Hungary and Poland became members of the EU in 2004.

BVAR models in the third part of the analysis are based on quarterly data in the same period. 3-month real money market interest rates defined above are averaged into quarterly figures. Macroeconomic data for the euro area and Czechia, Hungary and Poland are obtained from Eurostat: real GDP (seasonally adjusted data in constant prices, 2015=100), prices (harmonized index of consumer prices, HICP, $2015=100)^{26}$ and share of gross capital formation in GDP (seasonally adjusted data). Real interest rates and investment ratios are included in models in levels, while real GDP and HICP in log-differences. Before we move to the empirical analysis we provide some stylized facts to motivate our analysis.

Figure 1 shows real interest rate differentials in Czechia, Hungary and Poland visa-vis the euro area. Overall, we can conclude that real interest rate differentials in these CEE countries are relatively stable if we analyze the whole period and that they are lower compared to the pre-crisis period. Also, we can see that interest rate differential was in Czechia was the most stable one.

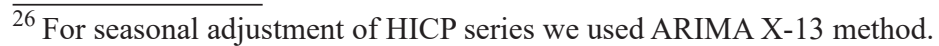


Figure 1: Real interest rate differentials in Czechia, Hungary, Poland and the euro area

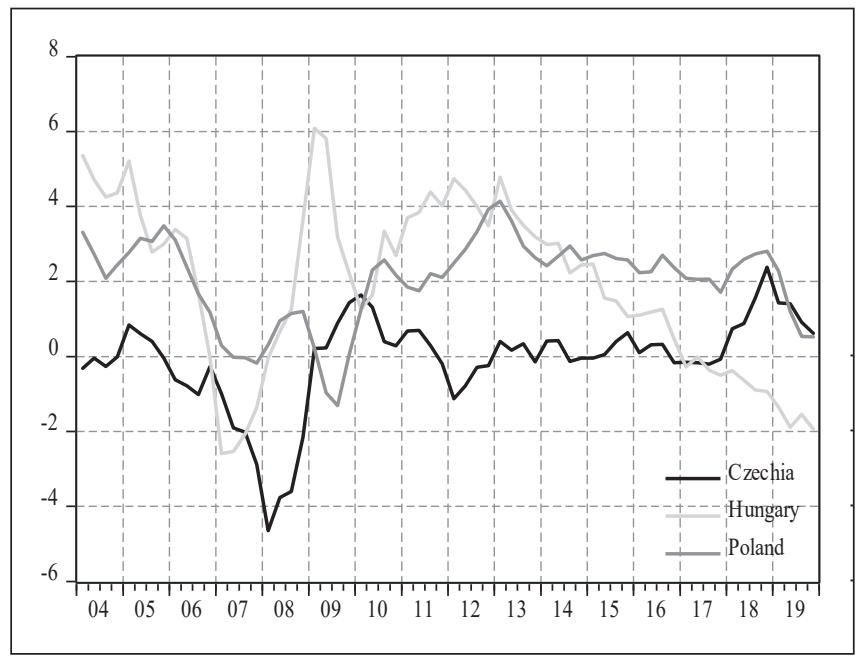

(a) original data

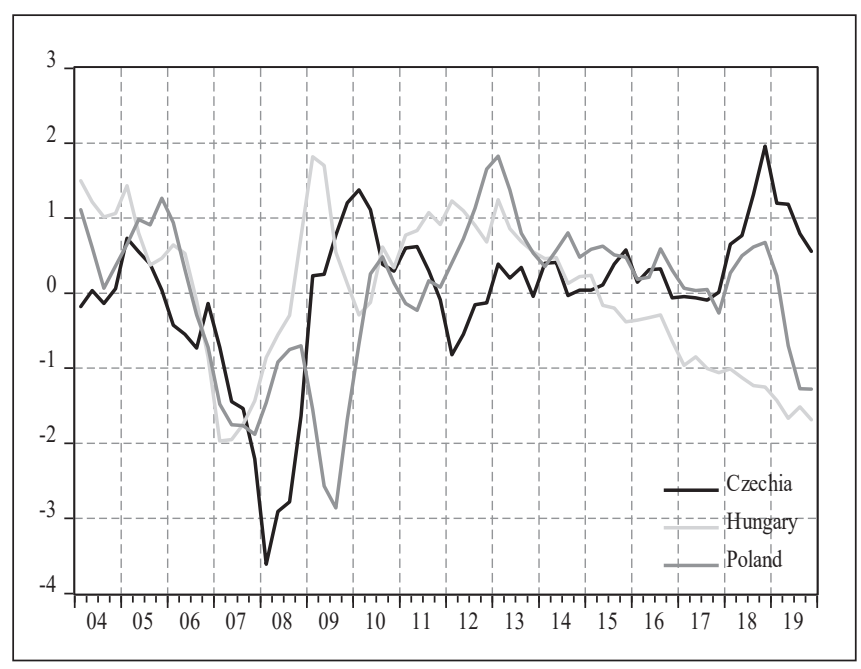

(b) normalized data

Source: Eurostat; authors' calculations

However, if we focus on sub-periods we can identify episodes of greater and lower volatility. For Czechia and Poland we can identify volatile periods before the GFC, during the European debt crisis and after 2017. In Hungary we can also observe period of high volatility up to 2009 and during the European debt crisis. After 2013 we can see a secular decline in real interest rate differential in this country. 


\section{Figure 2: Decomposition of real interest rate differentials}

(a) Czechia

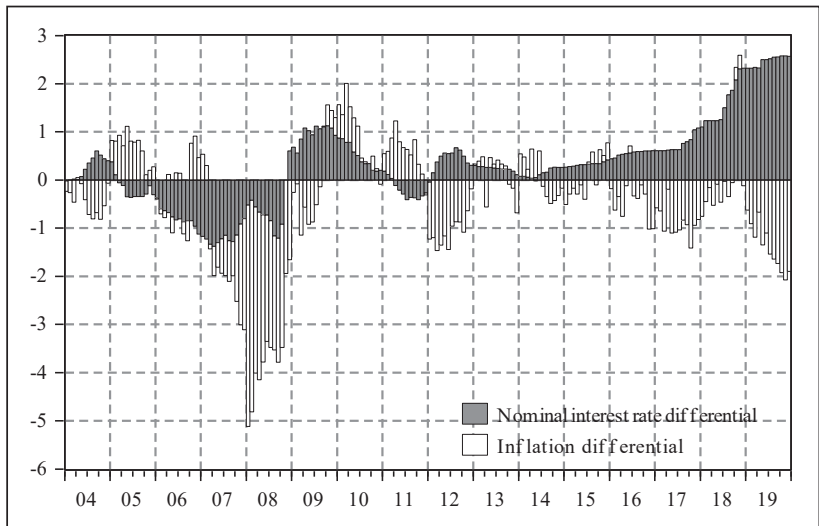

(b) Hungary

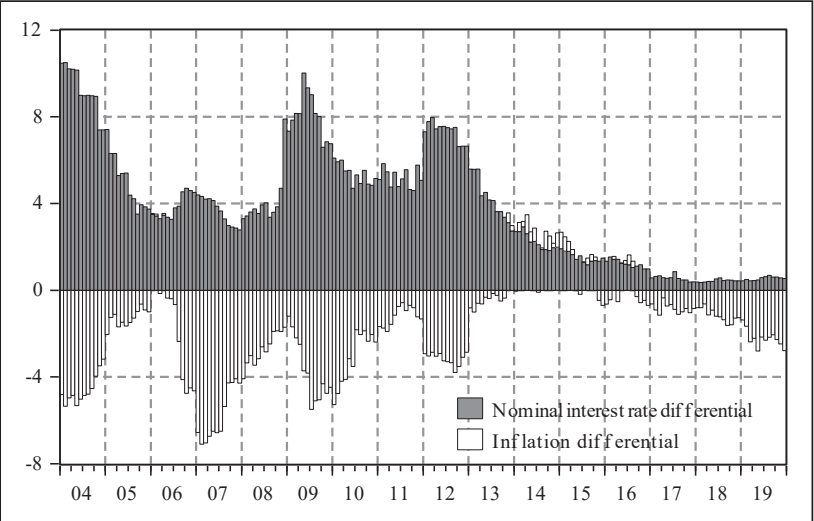

(c) Poland

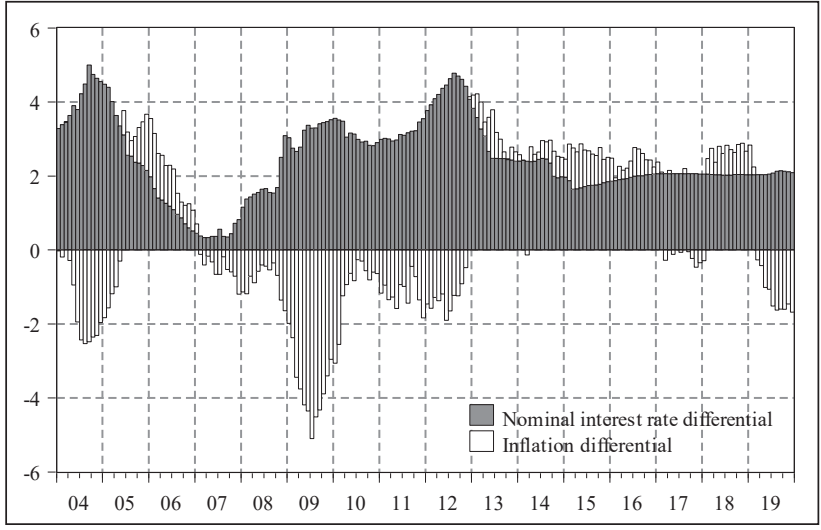

Note: As stated in the Related literature section, RIHP is based on Fishers equation, UIP and PPP. Combining these relations we can decompose real interest rate differential as: rid $_{t}=\left(i_{t}-i_{t}{ }^{*}\right.$ $\left.\Delta s_{t}^{e}\right)-\left(\pi_{t}-\pi_{t}^{*}-\Delta s_{t}^{e}\right)$. This is equal to: $\operatorname{rid}_{t}=\left(i_{t}-i_{t}^{*}\right)-\left(\pi_{t}-\pi_{t}^{*}\right)$, where superscript ${ }^{*}$ stands for foreign variables. Inflation differential is presented with the opposite sign (negative inflation differential indicates that inflation is higher in CEE than in the euro area)

Source: Authors' calculations 
To get a clearer picture on determinants of interest rate differentials and to better understand sources of volatility during some periods, on Figure 2 we decompose real interest rate differentials in nominal interest rate differentials and inflation differentials. ${ }^{27}$ Figure shows that inflation differentials played a dominant role in the period before the GFC in Czechia, while in Poland and Hungary both differentials had significant effect on real interest rate differential. During the European debt crisis nominal interest rate differential vanished in Czechia so inflation differential had decisive role, while in Hungary and Poland both differentials had notable contribution. Interestingly figure also shows that in the period from 2013 to approximately 2017 inflation rate differential disappeared in all countries, during the period of the so-called "missing inflation" in Europe (Bobeica and Jarocinski, 2017). After 2017 inflation differentials started to play important role again as inflation rates in CEE countries picked up. It is also important to notice that in this period nominal interest rate differential started to increase in Czechia as Czech National Bank started with rate hikes after exchange rate targeting policy fueled inflation (Bruha and Tonner, 2018), while it became negligible in Hungary, as Hungarian National Bank pursued expansionary monetary policy. Polish National Bank kept key policy rate unchanged since 2015 so most changes in real interest rate differential in this country can be attributed to inflation differentials.

Although this descriptive analysis gives some important insights it can't give some reliable evidence regarding the real interest rate parity (RIRP), which is the starting point of our empirical analysis. Thus, Table 2 presents results of various unit root tests. As we explained earlier, in order for RIRP to hold, real interest rate differentials have to be stationary.

Table 2: Unit root tests

\begin{tabular}{|l|c|c|c|c|}
\hline & ADF & PP & KPSS & ZA \\
\hline Czechia & 0.16 & 0.18 & $0.45^{*}$ & $0.00 * * *$ \\
\hline Hungary & 0.38 & 0.31 & $0.51^{*}$ & $0.00 * * *$ \\
\hline Poland & 0.31 & 0.13 & $0.47 *$ & $0.00 * * *$ \\
\hline
\end{tabular}

Note: Numbers in the table present p-value for ADF, PP and ZA test and LM-stat for KPSS test; * indicates that variable is stationary at the level of statistical significance of $10 \%$; $* * *$ indicates that variable is stationary at the level of statistical significance of $1 \%$

Source: Authors' calculations

Results presented in the table show that according to ADF and PP tests we cannot reject the null hypothesis that series contain unit root (non-stationarity). On the other hand, KPSS test indicates that series are stationary at the level of significance

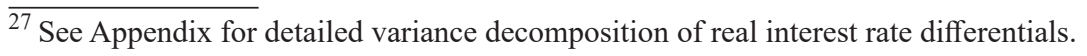


of $10 \%$. As we discussed earlier, one of the main weaknesses of standard unit root tests is that they are sensitive to potential structural breaks. Hence, we also employed ZA test which indicates that series are stationary at $1 \%$ level of significance (with structural break in all series in 2008). These tests indicate that RIRP holds for the countries in the sample, which is in line with conclusions of the papers presented in the literature review.

Figure 3: Real interest rates (original and normalized data)
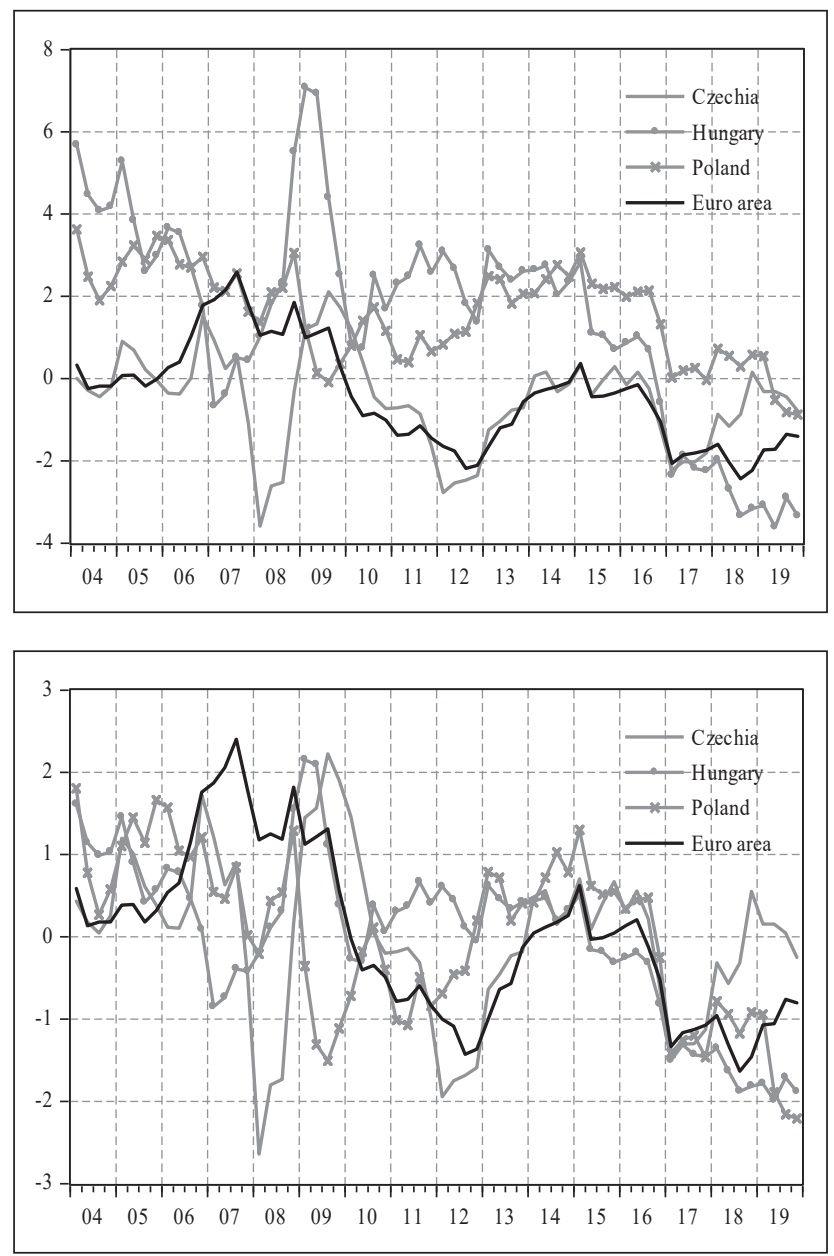

Source: Eurostat; authors' calculations

Stationarity of real interest rate differentials implies that real interest rates in CEE counters and the euro area are driven by some common factors. Thus, on Figure 3 we show developments of real interest rates. The figure leads to several conclusions, 
(expectedly) in line with the discussion on real interest rate differentials. First, there is a visible correlation between real interest rate in the euro area and real interest rates in CEE countries. Second, the sample can be clearly split on two subsamples: volatile pre-crisis period up to the end of 2009 and more stable post-crisis period after 2009. After 2009, and especially after 2014, real interest rates in CEE countries stabilized and correlation with the euro are increased.

These conclusions are supported by the correlation coefficients presented in Table 3 . In the pre-crisis period, correlations of real interest rates between CEE countries and the euro area were low or even negative. In the crisis period (GFC in 2009 and European debt crisis 2011/12) correlations coefficients turned positive and increased substantially. In the period from 2014, correlation coefficients remained on the relatively high levels in all countries.

Table 3: Correlation of real interest rates in the CEE and the euro area

\begin{tabular}{|l|c|c|c|c|}
\hline & $2004-2008$ & $2009-2013$ & $2014-2019$ & $2004-2019$ \\
\hline Czechia & 0.02 & 0.90 & 0.64 & 0.45 \\
\hline Hungary & -0.65 & 0.67 & 0.92 & 0.46 \\
\hline Poland & -0.11 & -0.40 & 0.85 & 0.51 \\
\hline
\end{tabular}

Source: Authors' calculations

Strong correlation and convergence of real interest rates (implied by analysis of stationarity) implies that these economic could be driven by some common factors. Thus, as explained in the previous section, we employ principal component analysis (PCA) to extract common factors and test whether common factors can explain notable part of the variance of real interest rates in these countries. Table 4 shows the cumulative proportion of variance of real interest rates explained by common factors.

Table 4: Cumulative proportion of variance of real interest rates explained by common factors

\begin{tabular}{|l|c|c|c|c|}
\hline & $2004-2008$ & $2009-2013$ & $2014-2019$ & $2004-2019$ \\
\hline PC 1 & 0.59 & 0.70 & 0.81 & 0.60 \\
\hline PC 2 & 0.71 & 0.83 & 0.87 & 0.71 \\
\hline PC 3 & 0.79 & 0.88 & 0.93 & 0.78 \\
\hline PC 4 & 0.85 & 0.92 & 0.95 & 0.85 \\
\hline PC 5 & 0.89 & 0.95 & 0.99 & 0.92 \\
\hline
\end{tabular}

Source: Authors' calculations 
Numbers presented in Table 4 are in line with the conclusions based on correlation analysis. In the pre-crisis period, $90 \%$ of the variance of real interest rates was explained by more than five factors, in the period of GFC and European debt crisis by four common factors and after 2014 by three common factors, indicating that synchronization of real interest rates increased notably over time.

Results of unit root tests and principle component analysis presented in this section indicate that real interest rates in the euro area and selected CEE countries show convergence patters and that they are partially driven by some common factors. In the next section we analyze this finding in more details in a more rigorous analytical framework.

\section{Results and discussion}

In this section we present the results of two main methodological approaches describes in Section 3. First, we analyze the contribution of common factor obtained by the principal component analysis to developments of real interest rates in selected CEE countries, using simple regression analysis. Then we move to more detailed analysis through the lenses of structural BVAR model.

\subsection{Contribution of common factor do developments of real interest rates in CEE}

Figure 4 graphically presents estimation results of (2), with the first principle component. It shows that contribution of common factor is fairly pronounced in all countries, especially in Czechia and Poland. 
Milan Deskar-Škrbić, Antonija Buljan, Mirna Dumičić • Real interest rate convergence...

Figure 4: Contribution of common factor to developments of real interest rates (\%)

(a) Czechia

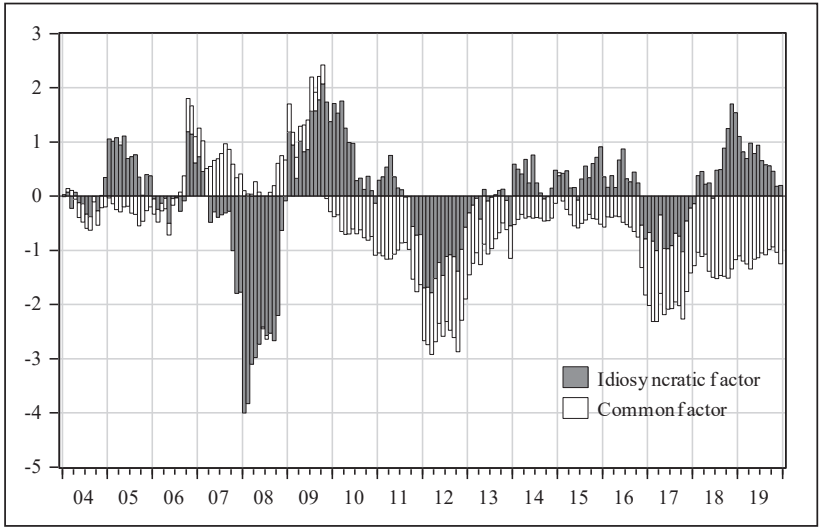

(b) Hungary

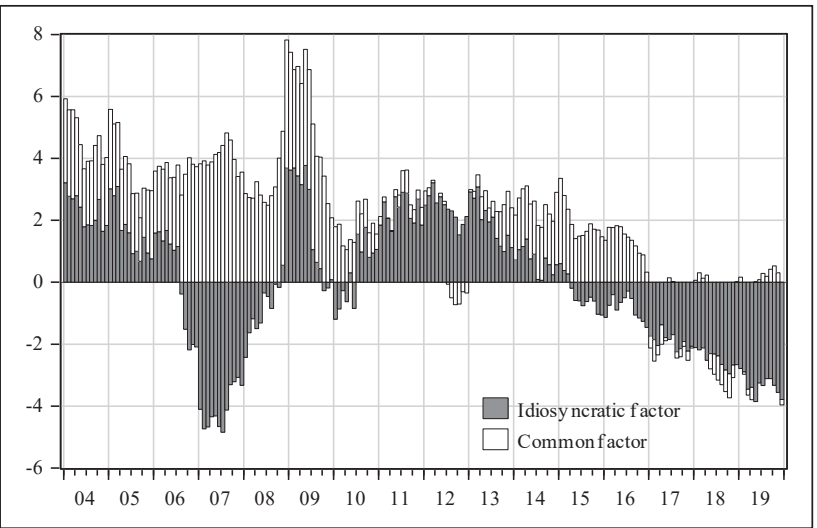

(c) Poland

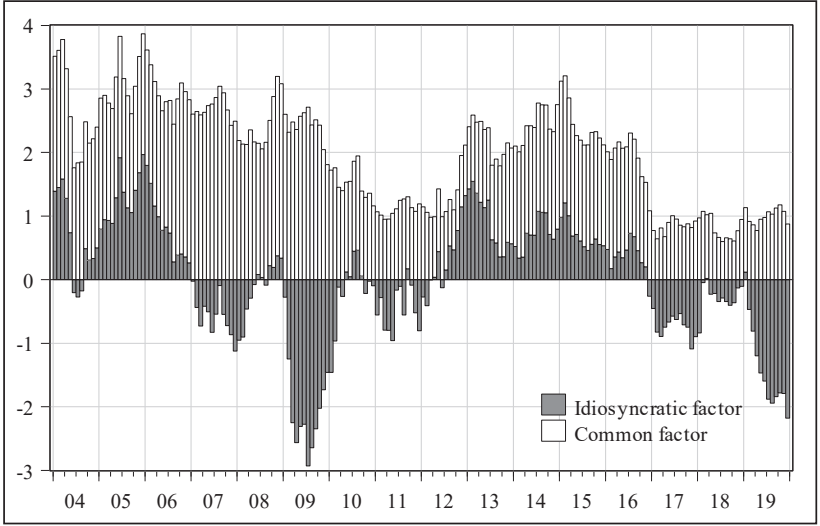

Source: Authors' calculations

However, figure also points to some interesting findings. Firstly, although GFC was a common global shock, our results indicate that idiosyncratic factors played 
very important role for developments of real interest rates. ${ }^{28}$ This can be explained by the fact that GFC primarily hit large euro area economies, which then spilledover to CEE with some lag. Also, ECB reacted to GFC shock somewhat earlier compared to national banks in CEE (especially in Poland), while inflation in more developed countries recorded stronger decline compared to CEE. Second, during the European debt crisis we can see increase of idiosyncratic component in all CEE countries, which is not surprising as this was primarily euro area crisis, with relatively limited spillovers to CEE. In the period of "missing inflation" we can detect rise of a common component, as this low inflationary environment was a kind of "new normal" across Europe. Finally, in the last few years of the sample we can observe increase of the idiosyncratic component, which is in line with the discussion presented in the previous section.

Although PCA is a very useful tool in this kind of analysis, it is purely empirical. It cannot provide a framework for understanding of the nature of idiosyncratic and common shocks that drive variables of interest. Thus, to give our analysis more theoretical rigor in the next section we analyze the contribution of theoreticallyfounded structural shocks identified in the structural BVAR model.

\subsection{Contributions of external shocks to developments of real interest rates in CEE}

VAR analysis provides three main types of results: impulse response functions (IRF), forecast error variance decomposition (FEVD) and historical decomposition (HD) (Killian and Lutkepohl, 2017).

In this paper we are mostly interested in historical decompositions of real interest rates in selected CEE countries. By definition, historical decomposition decomposes each endogenous variable in the model into contribution of each identified shock by multiplying impulse response function by structural shock in every period. Thus, unlike purely empirical approaches such as PCA, historical decompositions provide a richer analytical framework for the analysis of the nature of shocks that drive real interest rates in our sample.

Figure 5 presents historical decompositions of real interest rates for countries in our CEE sample. To make our result more comprehensive we cumulated shocks presented in Table 1 into two groups: domestic and external. Contributions of individual shocks are presented in Appendix.

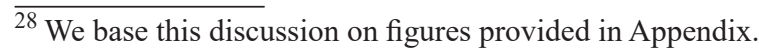


Milan Deskar-Škrbić, Antonija Buljan, Mirna Dumičić • Real interest rate convergence... Zb. rad. Ekon. fak. Rij. • $2020 \bullet$ vol. $38 \cdot$ no. $2 \cdot 349-380$

Figure 5: Historical decompositions of real interest rates (deviations from the baseline)

(a) Czechia

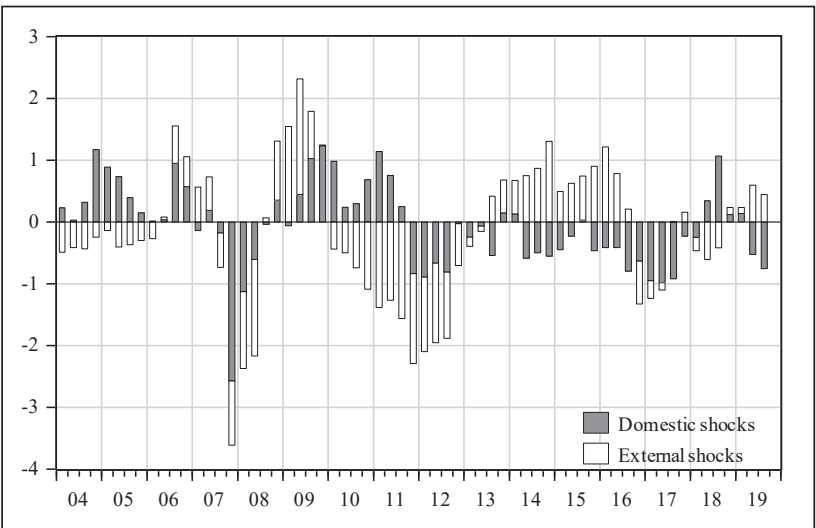

(b) Hungary

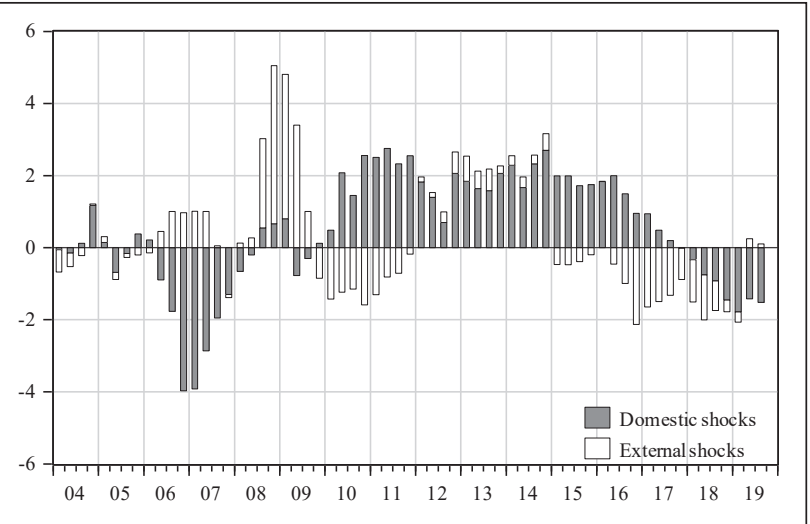

(c) Poland

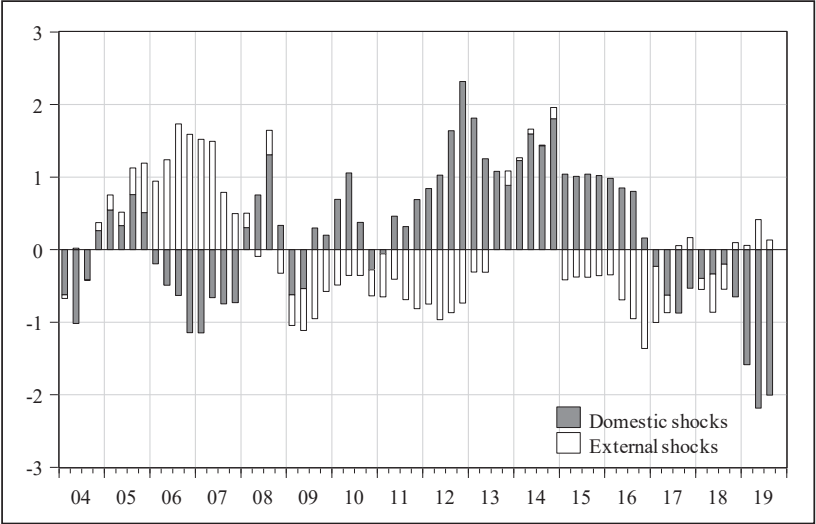

Source: Authors' calculations 
Figure shows that in the observed period external shocks played dominant role for developments of real interest rate in Czechia, which is in line with previous conclusions based on other methodological approaches in this paper. Contribution of external shocks to developments of real interest rates in other two countries is not so pronounced but still it is far from negligible. ${ }^{29}$ External shocks played important role in Czechia in Hungary during the GFC and during the missing inflation period. During the sovereign debt crisis contribution of external shocks was pronounced only in case of Czechia (see for example Deskar-Škrbić et al., 2020), while for other two countries this period was marked by dominance of idiosyncratic shocks.

\section{Conclusions}

Empirical results presented in this paper show that real money market interest rates in Czechia, Hungary and Poland show patterns of convergence with the euro area. Thus, we found empirical evidence for the validity of RIRP, in line with previous research presented in the literature review. However, unlike many other authors in this field of research we took a step forward and tried to shed some new light on the reasons why RIRP holds for these countries.

We analyzed whether there are some common factors that prevent real interest rates in CEE countries to diverge from real interest rates in the euro area. Our results show that historical developments of real interest rates can be adequately described by the common factor extracted from real interest rates in these countries and individual euro area countries. In addition, we showed that external shocks have notable effects on real interest rates in these countries. However, our results also showed that there are differences between countries in our sample. Real interest rates in Czechia are mostly determined by external shocks, while the contribution of external shocks in Hungary and, especially, Poland is less pronounced. These findings are not surprising as previous research shows that the relevance of external shocks in these countries is lower compared to Czechia. However, the relevance of external shocks in the other two countries is still far from negligible.

Bottom line, our results indicate that real interest rates in CEE depend on factors that are beyond the scope of domestic monetary policy makers. In this sense we can conclude that (conventional) monetary policy independece in these countries is limited. In this context we see the loss of monetary policy independence overly pronounced argument in discussion on euro adoption in these countries. Our

\footnotetext{
${ }^{29}$ Effects of external shocks on real interest rate developments on CEE countries are mostly transmitted through the effects of these shocks on domestic GDP and inflation. Thus, our results are in line with conclusions of Deskar-Škrbić et al. (2020) and Deskar-Škrbić and Kunovac (2020) who show that contribution of external shocks to GDP and HICP developments in Czechia is more pronounced compared to Hungary and Poland.
} 
findings are mostly in line with conclusions of previous research. However, this is the first paper that provides evidence for the hypothesis of limited monetary policy independence in these countries based on decompositions of real interest rates.

We are well aware of some shortcomings of our analysis. First, in this paper we focus solely on the conventional monetary policy tools both in CEE and the euro area, while unconventional monetary policy is the new game in town. Our choice of this approach was motivated by the desire for our results to be comparable to previous research in this field, which was mostly based on conventional monetary policy. Second, due to relatively short sample we could not provide robustness check by splitting the sample, which is common in VAR literature. Third, as for the same reason we wanted to keep our BVAR model parsimonious, we identified relatively low number of structural shocks, especially in the external block. It would be very interesting to analyze the contribution of the euro area monetary policy shock in this context. Thus, our results should be interpreted with the grain of salt.

However, we hope that our findings can motivate other authors to additionally explore relevance of common and external shocks for real interest rate developments in these countries in the context of monetary policy independence. This is especially important topic in the current environment shaped by the global exogenous COVID-19-related shock that affected both euro area and CEE economies and led to strong synchronized reaction of policy makers in all countries. With similar GDP and inflation developments and similar reactions of policy makers, current events suggest that we could see even stronger convergence of real interest rates in the future.

\section{References}

Aizenman, J., Chinn, M.D., Ito, H. (2013) "The "impossible trinity" hypothesis in an era of global imbalances: measurement and testing," Review of International Economics, Vol. 21, No. 3, pp. 447-458, https://doi.org/10.1111/roie.12047.

Aksoy, Y., De Grauwe, P., Dewachter, H. (2002) "Do asymmetries matter for European monetary policy?”, European Economic Review, Vol. 46, No. 3, pp. 443-469, https://doi.org/10.1016/S0014-2921(01)00160-X.

Alesina, A., Barro, R., Tenreyro, S. (2002) "Optimal Currency Areas," NBER Macroeconomic Annual 2002. Cambridge, MA: MIT Press: pp. 301-355, https://www.journals.uchicago.edu/doi/abs/10.1086/ma.17.3585292.

Alexius, A. (2017) "Why are real interest rates so low? Evidence from a structural VAR with sign restrictions", Research Papers in Economics, No. 6, Stockholm University, Department of Economics, https://www.diva-portal.org/smash/ record.jsf?pid=diva2\%3A1279929\&dswid=5308. 
Angeloni, I., Flad, M., Mongelli, F. P. (2007) "Monetary integration of the new EU Member States: What sets the pace of euro adoption?", JCMS: Journal of Common Market Studies, Vol. 45, No. 2, pp. 367-409, https://doi.org/10.1111/ j.1468-5965.2007.00715.x.

Arčabić, V. (2011) "Usklađenost poslovnih ciklusa Republike Hrvatske sa zemljama Europske unije”, Zbornik Ekonomskog fakulteta u Zagrebu, Vol. 9, No. 1, pp. 127-144, https://hrcak.srce.hr/70799.

Arghyrou, M.G., Gregoriou, A. (2007) "Testing for Purchasing Power Parity correcting for non-normality using the wild bootstrap", Economics Letters, Vol. 95, No. 2, pp. 285-290, https://doi.org/10.1016/j.econlet.2006.10.022.

Arghyrou, M.G., Gregoriou, A., Kontonikas, A. (2009) "Do real interest rate converge? Evidence from the European Union", Journal of International Financial Markets, Institutions and Money, Vol. 19, No. 3, pp. 447-460, https:// doi.org/10.1016/j.intfin.2008.05.004.

Arias, J., Rubio-RamÌrez, J. F., and Waggoner, D. F. (2014) "Inference Based on SVAR Identified with Sign and Zero Restrictions: Theory and Applications", International Finance Discussion Papers, No. 1100, https://doi.org/10.3982/ ECTA14468.

Bayoumi, T., Eichengreen, B. (1992) "Shocking aspects of European monetary unification", National Bureau of Economic Research, No. w3949, https://www. nber.org/papers/w3949.

Benecka, S., Fadejeva, L., Feldkircher, M. (2018) "Spillovers from Euro Area Monetary Policy: A Focus on Emerging Europe”, Working Papers, No. 2018/2, Czech National Bank, https://www.macroeconomics.lv/sites/default/files/ $2018-10 /$ spillovers $\% 20$ from $\% 20$ euro $\% 20$ area $\% 20$ monetary $\% 20$ policy $\% 20$ wp_4-2018_en.pdf.

Benkovskis K., Bessonovs A., Feldkircher M., Worz, J. (2011) "The transmission of euro area monetary shocks to the Czech Republic, Poland and Hungary: evidence from a FAVAR model", Focus on Euro Econ Integration, No. 3, pp. 8-36, https://ideas.repec.org/a/onb/oenbfi/y2011i3b1.html.

Bernard, A., Durlauf, S. (1996) "Interpreting tests of the convergence hypothesis", Journal of Econometrics, Vol. 71, No. 1-2, pp. 161-173, https://doi.org/10.1016/ 0304-4076(94)01699-2.

Bobeica, E., Jarocinski, M. (2017) "Missing disinflation and missing inflation: the puzzles that aren't”, ECB Working Paper, No. 2000, https://papers.ssrn.com/ sol3/papers.cfm?abstract_id=2910914.

Botrić, V., Broz, T., Jakšić, S. (2020) "Business cycle synchronisation with the euro area countries at times of crisis: differences between SEE and CEE countries", South-Eastern Europe Journal of Economics, Vol. 17, No. 2, https://ojs.lib.uom. gr/index.php/seeje/article/view/9640. 
Broz, T. (2005) "The Theory of Optimum Currency Areas: A Literature Review"e. Privredna kretanja i ekonomska politika, No. 15, https://scholar.google.hr/ scholar?hl=hr\&as_sdt $=0 \% 2 \mathrm{C} 5 \& \mathrm{q}=\mathrm{Broz} \% 2 \mathrm{C}+\mathrm{T} .+\% 282005 \% 29+\% \mathrm{E} 2 \% 80 \% 9 \mathrm{~F}$ The + Theory + of + Optimum + Currency + Areas $\% 3 \mathrm{~A}+\mathrm{A}+$ Literature + Review $\%$ E2 $\% 80 \% 9 \mathrm{~F}$.+Privredna + kretanja $+\mathrm{i}+\mathrm{ekonomska}+\& \mathrm{btnG}=$.

Broz, T. (2010) "Introduction of the euro in CEE countries-is it economically justifiable? The Croatian case", Post-Communist Economies, Vol. 22, No. 4, pp. 427-447, https://doi.org/10.1080/14631377.2010.518449.

Brůha, J., Tonner, J. (2017) "An exchange rate floor as an instrument of monetary policy: An ex-post assessment of the Czech experience", Czech National Bank, Working paper series, No. 4, https://www.cnb.cz/export/sites/cnb/en/economicresearch/.galleries/seminars_workshops/2018/rod_2018_10_tonner.pdf.

Calvo, G.A., Reinhart, C.M. (2002) "Fear of Floating," Quarterly Journal of Economics, Vol. 107, No. 2, pp. 379-408, https://doi.org/10.1162/003355302753650274.

Campos, N. F., Fidrmuc, J., Korhonen, I. (2019) "Business cycle synchronisation and currency unions: A review of the econometric evidence using metaanalysis", International Review of Financial Analysis, Vol. 61, pp. 274-283, https://doi.org/10.1016/j.irfa.2018.11.012.

Carlin, W., Soskice, D.W. (2014) Macroeconomics: Institutions, instability, and the financial system, Oxford University Press, USA.

Carrion-i-Silvestre, J.L., Del Barrio-Castro, T., Lopez-Bazo, E. (2005) "Breaking the panels: an application to the GDP per capita", The Econometrics Journal, Vol. 8, No. 2, pp. 159-175, https://doi.org/10.1111/j.1368-423X.2005.00158.x.

Ca'Zorzi, M. et al. (2020). "Monetary policy and its transmission in a globalised world", ECB Working Paper, No. 2405, https://papers.ssrn.com/sol3/papers. cfm?abstract_id $=3599928$.

Chinn, M., Frankel, J. (1995) "Who drives real interest rates around the Pacific Rim: the USA or Japan?", Journal of International Money and Finance, Vol. 14, No. 6, pp. 801-821, https://doi.org/10.1016/0261-5606(95)00038-0.

Cuaresma, J.C., Wójcik, C. (2006) "Measuring monetary independence: Evidence from a group of new EU member countries", Journal of Comparative Economics, Vol. 34, No.1, pp. 24-43, https://doi.org/10.1016/j.jce.2005.12.003.

Cuestas, J.C., Harrison, B. (2010) "Further evidence on the real interest rate parity hypothesis in Central and East European countries: unit roots and nonlinearities", Emerging Markets Finance and Trade, Vol. 46, No. 6, pp. 22 39, https://doi.org/10.2753/REE1540-496X460602.

Cumby, R., Mishkin, F. (1986) "The international linkage of real interest rates: The European-U.S. connection”, Journal of international Money and Finance, Vol. 5, No. 1, pp. 5-23.

Dąbrowski, M. A., Papież, M. and Śmiech, S. (2019) „Monetary Independence of Central and Eastern European Economies with Flexible Exchange Rate 
Regimes“, Eastern European Economics, Vol. 57, No. 4, pp. 295-316, https:// doi.org/10.1080/00128775.2019.1610897.

Deskar-Škrbić, M., Kotarac, K., Kunovac, D. (2020) "The third round of euro area enlargement: Are the candidates ready?", Journal of International Money and Finance, Vol. 107, No. 102205, https://doi.org/10.1016/0261-5606(86)90047-1.

Deskar-Škrbić, M., Kunovac, D. (2020) "Twentieth Anniversary of the Euro: Why are Some Countries Still Not Willing to Join? Economists' View", Comparative Economic Studies, pp. 1-21.

Dickey, D.A., Fuller, W.A. (1979) "Distribution of the Estimators for Autoregressive Time Series with a Unit Root", Journal of the American Statistical Association, Vol. 74, No. 366, pp. 427-431, https://doi.org/10.1080/01621459.1979.1048253 1.

Dutton, M. M. (1993) "Real interest rate parity: new measures and tests", Journal of International Money and Finance, Vol. 14, No. 1, pp. 801-825, https://doi. org/10.1016/0261-5606(93)90010-9.

Edwards, S. (2015) "Monetary policy independence under flexible exchange rates: an illusion?", The World Economy, Vol. 38, No. 5, pp. 773-787, https://doi. org/10.1111/twec. 12262 .

Enders, W., Lee, J. (2012) “A Unit Root Test Using a Fourier Series to Approximate Smooth Breaks", Oxford Bulletin of Economics and Statistics, Vol. 74, No. 4, pp. 574-599, https://doi.org/10.1111/j.1468-0084.2011.00662.x.

Estrin, S., Uraga, G. (1997) "Testing for Ongoing Convergence in Central and Eastern Europe", CEPR Discussion Paper, No. 1615.

Eudey, G. (1998) "Why is Europe Forming a Monetary Union?", Federal Bank of Philadelphia, Business Review, Nov/Dec, pp. 13-21, http://citeseerx.ist.psu. edu/viewdoc/download?doi=10.1.1.196.1036\&rep=rep1\&type=pdf.

Feldkircher, M. (2015) “A global macro model for emerging Europe," Journal of Comparative Economics, Vol. 43, No. 3, pp. 706-726, https://doi.org/10.1016/j. jce.2014.09.002.

Ferreira, A.L., Leon-Ledesma, M. A. (2007) "Does the real interest parity hypothesis hold? Evidence for developed and emerging markets", Journal of International Money and Finance, Vol. 26, No. 3, pp. 364-382, https://doi. org/10.1016/j.jimonfin.2006.11.003.

Fidrmuc, J., Korhonen, I. (2006) "Meta-analysis of the business cycle correlation between the euro area and the CEECs", Journal of Comparative Economics, Vol. 34, No. 3, pp. 518-537, https://doi.org/10.1016/j.jce.2006.06.007.

Frankel, J.A., Rose, A.K. (1998) "The Endogeneity of the Optimum Currency Area Criteria", The Economic Journal, Vol. 108, No. 449, pp. 1009-1025, https://doi. org/10.1111/1468-0297.00327Galí, J. (2008) Monetary Policy, Inflation, and the Business Cycle: An Introduction to the New Keynesian Framework, Princeton, N.J: Princeton University Press. 
Galì, J., Gertler, M. (2007) "Macroeconomic Modeling for Monetary Policy Evaluation", The Journal of Economic Perspectives, Vol. 21, No. 4, pp. 25-45, https://pubs.aeaweb.org/doi/pdfplus/10.1257/jep.21.4.25.

Goczek, L., D. Mycielska (2019) "Actual monetary policy independence in a small open economy: The Polish perspective," Empirical Economics, Vol. 56, No. 2, pp. 499-522, https://doi.org/10.1007/s00181-017-1370-y.

Goczek, Ł., Mycielska, D. (2016) "Euro Dominance Hypothesis and Monetary Policy Independence-the Czech Perspective", Prague Economic Papers, Vol. 2016, No. 6, pp. 655-670, doi: 10.18267/j.pep.584.

Goodwin, B.K., T.J. Grennes (1994) "Real interest rate equalisation and the integration of international financial markets", Journal of International Money and Finance, Vol. 13, No. 1, pp. 107-124, https://doi.org/10.1016/0261-5606 (94)90027-2.

Hanclova, J. (2012) "The effects of domestic and external shocks on a small open country: The evidence from the Czech Economy", International Journal of Mathematical Models and Methods in Applied Sciences, Vol. 6, No. 2, pp. 366375, http://citeseerx.ist.psu.edu/viewdoc/download?doi=10.1.1.352.5855\&rep= rep1\&type $=$ pdf.

Holmes, M.J. (2002) "Does long-run real interest parity hold among EU countries? Some new panel data evidence", The Quarterly Review of Economics and Finance, Vol. 42, No. 4, pp. 733-746, https://doi.org/10.1016/S1062-9769(01) 00116-8.

Holmes, M.J. (2005) "Integration or independence? An alternative assessment of real interest rate linkages in the European Union", Economic Notes, Vol. 34, No. 3, pp. 407-427, https://doi.org/10.1111/j.0391-5026.2005.00156.x.

Horvath, R., Rusnak, M. (2009) "How important are foreign shocks in a small open economy? The case of Slovakia", Global Economy Journal, Vol. 9, No. 1, https://doi.org/10.2202/1524-5861.1420.

Iossifov, P., Podpiera, J. (2014) “Are Non-Euro Area EU Countries Importing Low Inflation from the Euro Area?", IMF Working Papers, No.14/191.

Jiménez-Rodríguez, R., Morales-Zumaquero, A., Égert, B. (2013) "Business Cycle Synchronization between Euro Area and Central and Eastern European Countries", Review of Development Economics, Vol. 17, No. 2, pp. 379-395, https://doi.org/10.1111/rode.12038.

Kadow, A., Cerrato, M., MacDonald, R., Straetmans, S. (2013) „Does the euro dominate Central and Eastern European money markets?", Journal of International Money and Finance, Vol. 32, pp. 700-718.

Keppel, C., Prettner, K. (2015) "How interdependent are Eastern European economies and the Euro area?", The Quarterly Review of Economics and Finance, Vol. 58, pp. 18-31, https://doi.org/10.1016/j.qref.2015.02.012. 
Kilian, L., Lütkepohl, H. (2017) Structural vector autoregressive analysis, Cambridge University Press.

Kotarac, K., Kunovac, D., Ravnik, R. (2017) "Coherence of business cycles and economic shocks between Croatia and Euro Area Member States", CNB Working Papers, No. 53.

Krznar, I., Kunovac, D. (2010) "Utjecaj vanjskih šokova na domaću inflaciju i BDP”, Istraživanja, No. 1-28.

Kunovac, D. (2013) "Trošak zaduživanja odabranih zemalja Europske unije i Hrvatske - uloga prelijevanja vanjskih šokova”, HNB Istraživanja, No. 1-41.

Kunovac, D., Kotarac, K. (2017) BVAR under block exogeneity and sign restrictions: Matlab toolbox, Croatian National Bank.

Kwiatkowski, D., Phillips, P. C. B., Schmidt, P., Shin, Y. (1992) "Testing the null hypothesis of stationarity against the alternative of a unit root", Journal of Econometrics, Vol. 54, No. 1-3, pp. 159-178.

Macchiarelli, C. (2013) "GDP-Inflation cyclical similarities in the CEE countries and the euro area", ECB Working Paper, No. 5024, https://papers.ssrn.com/ sol3/papers.cfm?abstract_id $=2268505$.

Mackowiak, B. (2006) "How much of the macroeconomic variation in Eastern Europe is attributable to external shocks?", Comparative Economic Studies, Vol. 48, No. 3, pp. 523-544, https://doi.org/10.1057/palgrave.ces.8100143.

Mark, N.C. (1985) "Some evidence on the international equality of real interest rates", Journal of International Money and Finance, Vol. 4, No. 2, pp. 189-208, https://doi.org/10.1016/0261-5606(85)90043-9.

Meese, R., K. Rogoff (1988) "Was it real? The exchange rate-interest differential relation over the modern floating rate period", Journal of Finance, Vol. 43, No. 4, pp. 933-948, https://doi.org/10.1111/j.1540-6261.1988.tb02613.x.

Mishkin, F.S. (1984) "Are real interest rates equal across countries? An empirical investigation of international parity conditions", Journal of Finance, Vol. 39, No. 3, pp. 1345-1357, https://doi.org/10.1111/j.1540-6261.1984.tb04911.x.

Mongelli, F. (2002) "'New" views on the optimum currency area theory: What is EMU telling us?", ECB Working Paper, No. 138.

Narayan, P.K., Popp, S. (2010) "A New Unit Root Test with Two Structural Breaks in Level and Slope at Unknown Time", Journal of Applied Statistics, Vol. 37, No. 9, pp. 1425-1438, https://doi.org/10.1080/02664760903039883.

Ng, S., Perron, P. (2001) "Lag Length Selection and the Construction of Unit Root Tests with Good Size and Power", Econometrica, Vol. 69, No. 6, pp. 15191554, https://doi.org/10.1111/1468-0262.00256.

Obstfeld, M., Rogoff, K. (1996) Foundations of International Macroeconomics, MIT Press.

Obstfeld, M., Taylor, A.M. (2002) "Globalization and capital markets", NBER working paper, No. 8846, https://www.nber.org/system/files/chapters/c9587/c9587.pdf. 
Phillips, P., Perron, P. (1988) "Testing for a Unit Root in Time Series Regression", Biometrika, Vol. 75, No. 2, pp. 335-346, https://doi.org/10.1093/biomet/75.2.335.

Prettner, K., Prettner, C. (2014) "How Interdependent Are Eastern European Economies and the Euro Area?", SSRN Electronic Journal, No. 58, http://dx. doi.org/10.2139/ssrn.2393906.

Rey, H. (2015) "Dilemma not Trilemma: The Global Financial Cycle and Monetary Policy Independence," CEPR Discussion Papers 10591, C.E.P.R. Discussion Papers, https://www.nber.org/papers/w21162.

Rødseth, A. (2000) Open economy macroeconomics, Cambridge University Press.

Stanišić, N. (2013) "Convergence between the business cycles of Central and Eastern European countries and the Euro area", Baltic Journal of Economics, Vol. 13, No. 1, pp. 63-74.

Stock, J. H., Watson, M.W. (2002) "Macroeconomic Forecasting Using Diffusion Indexes", Journal of Business and Economic Statistics, Vol. 20, No. 2, pp. 147 162, https://doi.org/10.1198/073500102317351921.

Su, C. W., Chang, H. L., Liu, L. (2012) "Real interest rate parity with flexible Fourier stationary test for Central and Eastern European countries", Economic Modelling, Vol. 29, No. 6, pp. 2719-2723, https://doi.org/10.1016/j.econmod. 2012.06.017.

Su, C.W., Jiang, X., Chang, H.L. (2014) "Real interest rate parity for Central and Eastern European countries: a new unit root test with two structural breaks", Ekonomicky Casopis, Vol. 62, No.1, pp. 3-18, https://www.ceeol.com/search/ article-detail?id=163902.

Ter Ellen, S., Jansen, E., Midthjell, N.L., (2020) "ECB Spillovers and domestic monetary policy effectiveness in small open economies", European Economic Review, Vol. 121, https://doi.org/10.1016/j.euroecorev.2019.103338.

Walsh, C. E. (2010) Monetary Theory and Policy, Third Edition, Volume 1 of MIT Press Books, The MIT Press.

Woodford, M. (2003) Interest and Prices: Foundations of a Theory of Monetary Policy, Princeton, N.J., Woodstock, Oxfordshire England: Princeton University Press.

Wu, J.L., Fountas, S. (2000) "Real interest parity under regime shifts and implications for monetary policy", The Manchester School, Vol. 68, No. 6, pp. 685-700, https://doi.org/10.1111/1467-9957.00225.

Zivot, E., Andrews, D. (2012) "Further evidence of great crash, the oil price shock and unit root hypothesis", Journal of Business and Economic Statistics, Vol. 10, pp. 251-270, https://doi.org/10.1198/073500102753410372. 


\title{
Konvergencija realnih kamatnih stopa i neovisnost monetarne politike u zemljama Srednje i Istočne Europe
}

\author{
Milan Deskar-Škrbićn , Antonija Buljan ${ }^{2}$, Mirna Dumičić ${ }^{3}$
}

\begin{abstract}
Sažetak
U ovom radu daju se novi empirijski dokazi relevantni za rasprave o neovisnosti monetarne politike u kontekstu uvođenja eura u tri zemlje Srednje i Istočne Europe (CEE): Češkoj, Mađarskoj i Poljskoj. Za razliku od mnogih drugih autora, u ovom se radu težište stavlja na realne, a ne na nominalne kamatne stope, jer su realne kamatne stope u središtu moderne makroekonomske teorije i monetarne politike. $U$ istraživanju se primjenjuje nekoliko metodologija za ispitivanje konvergencije realnih kamatnih stopa između ovih zemalja i euro-područja kako bi se utvrdili glavne odrednice realnih kamatnih stopa. Na temelju testova jediničnog korijena nalazimo dokaze o konvergenciji realnih kamatnih stopa u tim zemljama, čime se potvrđuje hipoteza o realnom kamatnom paritetu (RIRP). Nadalje, primijenjena analiza glavnih komponenata (PCA) ukazuje na činjenicu da se zajedničkim faktorom izdvojenim iz uzorka zemalja Srednje i Istočne Europe i pojedinih zemalja euro-područja može objasniti visok udio kretanja realnih kamatnih stopa u tim zemljama. Konačno, rezultati našeg predloženog novog analitičkog okvira za analizu odrednica realnih kamatnih stopa u malim otvorenim gospodarstvima, temeljenog na Bayesovskom VAR modelu s pretpostavkom blok-egzogenosti (eng. block exogeneity ), pokazuju da vanjski šokovi imaju nezanemariv učinak na kretanje realnih kamatnih stopa u odabranim zemljama srednje i istočne Europe. Dakle, naši rezultati pokazuju da realne kamatne stope u SIE ovise o čimbenicima koji su izvan dosega domaćih kreatora monetarne politike. U tom smislu može se zaključiti da je (konvencionalna) neovisnost monetarne politike u tim zemljama ograničena. Stoga gubitak neovisnosti monetarne politike vidimo kao pretjerano naglašeni argument u raspravama o uvođenju eura u tim zemljama. Međutim, svjesni smo da su se nacionalne središnje banke u Srednjoj i Istočnoj Europi nedavno počele više oslanjati na nekonvencionalne mjere, što im daje veći stupanj fleksibilnosti (i autonomije).
\end{abstract}

Ključne riječi: uvođenje eura, realni kamatni paritet (RIRP), realne kamatne stope, Bayesovski VAR model, Srednja i Istočna Europa (SIE), Optimalno valutno područje (OCA)

JEL klasifikacija: E32, E52, F45

1 Viši ekonomski istraživač-savjetnik, Hrvatska narodna banka, Direkcija za modeliranje. Znanstveni interes: primijenjena makroekonomija, ekonomska politika, makroekonomija malih otvorenih gospodarstava.Tel.: +38514590313.E-mail:mdeskar@hnb.hr.

${ }^{2}$ Asistentica, Sveučilište u Zagrebu, Ekonomski fakultet, Katedra za financije. Znanstveni interes: javne financije, fiskalna politika, oporezivanje. Tel.: +385 1238 3170. E-mail: abuljan2@net.efzg.hr.

${ }^{3}$ Glavna savjetnica, Hrvatska narodna banka, Direkcija za financijsku stabilnost. Znanstveni interes: makrobonitetna politika, financijska stabilnost, makroekonomija malih otvorenih gospodarstava.Tel.: + 38514564879.E-mail: mirna.dumicic-jemric@hnb.hr. 
Milan Deskar-Škrbić, Antonija Buljan, Mirna Dumičić • Real interest rate convergence... Zb. rad. Ekon. fak. Rij. • 2020 • vol. $38 \cdot$ no. $2 \cdot 349-380$

\section{Appendices}

Appendix 1: Variance decomposition of real interest rate differentials

\begin{tabular}{|c|c|c|c|c|}
\hline & $\operatorname{Var}\left(i_{t}-i_{t}^{*}\right)$ & $\operatorname{Var}\left(\pi_{t}-\pi_{t}^{*}\right)$ & $2 * \operatorname{Cov}\left(i_{t}-i_{t}^{*}\right)$ & $\operatorname{Var}\left(r_{t}-r_{t}^{*}\right)$ \\
\hline \multicolumn{5}{|c|}{ Czechia } \\
\hline $2004-2008$ & 0.32 & 1.85 & 0.23 & 2.41 \\
\hline $2009-2012$ & 0.22 & 0.56 & -0.19 & 0.59 \\
\hline $2013-2017$ & 0.03 & 0.13 & -0.06 & 0.10 \\
\hline $2018-2019$ & 0.58 & 0.37 & -0.27 & 0.68 \\
\hline \multicolumn{5}{|c|}{ Hungary } \\
\hline $2004-2008$ & 5.34 & 4.18 & -2.66 & 6.85 \\
\hline $2009-2012$ & 1.90 & 1.79 & -1.95 & 1.74 \\
\hline $2013-2019$ & 1.71 & 0.80 & 6.98 & 0.48 \\
\hline \multicolumn{5}{|c|}{ Poland } \\
\hline $2004-2008$ & 2.04 & 1.19 & -1.67 & 1.56 \\
\hline $2009-2012$ & 0.34 & 1.70 & 0.14 & 2.18 \\
\hline $2013-2017$ & 0.22 & 0.11 & -0.09 & 0.24 \\
\hline $2018-2019$ & 0.00 & 0.64 & -0.04 & 0.60 \\
\hline
\end{tabular}

Source: Authors' calculations

Appendix 2: Some stylized facts on CEE economies

(a) Inflation rates

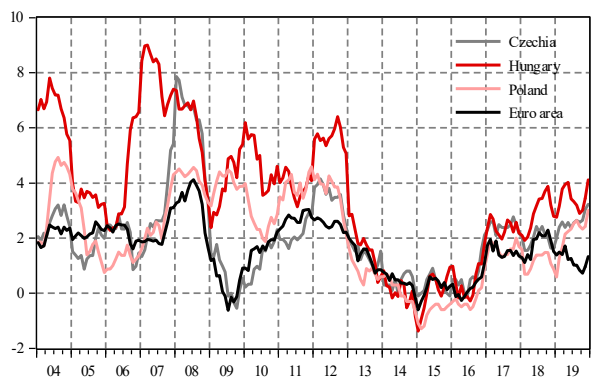

(c) Nominal money market rates

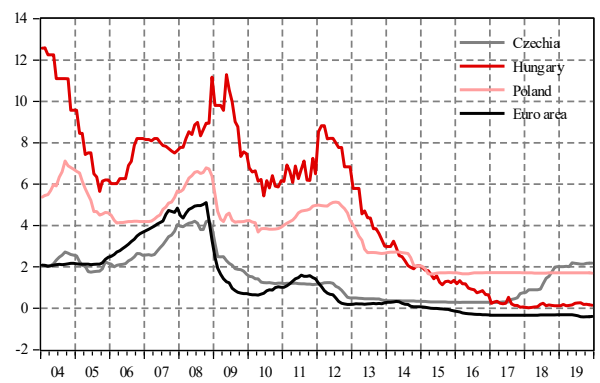

(b) Business cycles (HP)

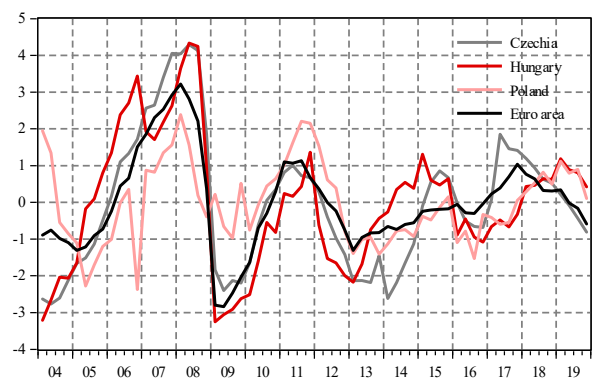

(d) Real money market rates

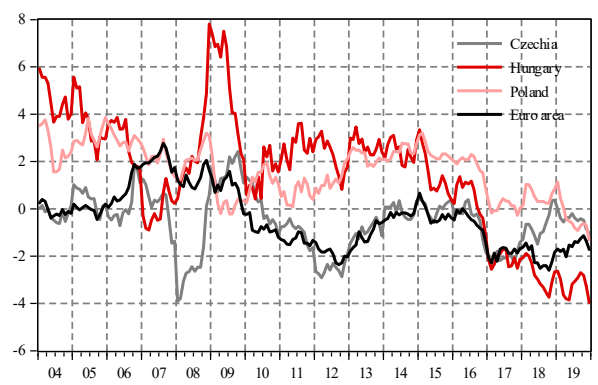

Source: Eurostat; authors' calculations 